\title{
A Most Brilliant Talker*
}

\section{ELIZABETH HEALEY}

Mr. Wells was slender and pale when I first met him ${ }^{1}$ - with remarkable blue eyes - and thick tumbled brown hair. He was very popular with his fellow students for he was sociable, amusing, friendly and a most brilliant talker - who was refreshing and stimulating - without ever showing malice or ill-nature. As a speaker in the Debating Society he never had an equal in my time. ${ }^{2}$ His wit was keen and swift - his sarcasm never wounded the victims of it - for it was tempered with humour and truth. He attacked conventions, shams and humbugs with all that courage of youth - which has never failed him throughout his later life. He loved 'cockshies' and smashing popular beliefs. As a teacher I knew nothing of him-I have always admired and appreciated everything he has written. I have one article never reprinted - 'Capital Punishment' ${ }^{3}$ which he wrote for the $S . S$. Journal - which I think does deserve a place in the permanent collection of his works.

* From the reminiscences (unpublished) of Elizabeth Healey.

\section{NOTES}

Elizabeth Bruce, née Healey (c 1863-1947), a fellow student with Wells at the Normal School of Science, South Kensington (1884-7) and a lifelong friend and correspondent.

I. She first met Wells as a student at the Normal School of Science (now the Imperial College of Science and Technology) in 1884 . Wells was then eighteen.

2. Wells was elected to the committee of the Debating Society in his first year as a student and played an active part in the Society throughout his student years.

3. 'On Capital Punishment', Science Schools Journal, no. 23 (Feb. I89o). 